\title{
CARCASS COMPOSITION AND CHEMICAL CHARACTERISTICS OF MEAT FROM BROILER CHICKENS REARED UNDER INTENSIVE AND SEMI- INTENSIVE SYSTEMS
}

\section{S. Bogosavljević-Bošković ${ }^{1}$ S. Mitrović ${ }^{2}$, V. Dosković ${ }^{1}$, S. Rakonjac ${ }^{1}$, V. Kurćubić $^{1}$}

${ }^{1}$ Faculty of Agronomy, Čačak, Cara Dušana 34, 32000 Cacak, Republic of Serbia

${ }^{2}$ Faculty of Agriculture, Belgrade-Zemun, Republic of Serbia

Corresponding author: sbb@tfc.kg.ac.rs

Original scientific paper

Abstract: Poultry rearing systems have captured the attention of scientists for many years. A number of attempts have been made to introduce new technologies in rearing poultry for meat and egg production aiming at improving rearing conditions, protecting the environment and enhancing the quality of poultry products. Given the above, the objective of this study was to present the results of an evaluation of the effect of rearing system on major meat quality traits (percent yield of primal cuts in cold carcasses, tissue percentage in major primal cuts and chemical composition of muscle tissue). The experiment involved a total of 400 Hybro broilers reared under two different systems (intensive and semi-intensive systems). The fattening period and slaughter and dressing procedures were followed by measurement and meat sampling for chemical analysis. The results obtained show that broilers reared under the semi-intensive system had a somewhat higher percentage of drumsticks and breasts i.e. first class meat, as well as a higher percentage of breast and thigh muscles. Moreover, the protein content of breast, thigh and drumstick muscles was higher in broilers reared under semi-intensive conditions. As for the fat content of primal cuts, it was found to exhibit higher values in broilers reared under the intensive system. Overall, the results suggest better performance for most traits in free range broilers reared under semi-intensive conditions as compared to those reared intensively.

Key words: broilers, rearing systems, meat quality.

\section{Introduction}

Modern poultry rearing tendencies in developed European countries necessitate definition of adequate innovative rearing technologies to meet the criteria regarding the production of biologically valuable food, animal protection and rationalization of the production process. 
European Union regulations on non-commercial, ecological and organic production are quite strict.

The most important requirements include housing under sufficient daylight conditions, limited stocking density i.e. limited number of birds per unit area, use of slow-growing chickens, and free-range recommendations.

Concerns regarding nutrition and length of fattening period are separately defined (Ristić, 2005).

The effect of rearing system on growth and meat quality of broilers has been studied by a number of authors (Lewis, 1997; Ristić, 1999; Damme and Rychlik, 2001; Holcman, 2003; Bogosavljević-Bošković et al., 2006a, 2010 etc.). Results of previous research (Bogosavljević-Bošković et al., 2006b, 2011) have shown that broiler hybrids most commonly reared in Serbia for intensive purposes can be successfully reared under semi-intensive i.e. free-range conditions. Certain meat quality traits obtained under this rearing system have proved to be better as compared to those of intensively reared broilers.

Given the above, the objective of this study was to evaluate the significance of differences in major meat quality traits (percent yield of primal cuts, tissue percentage in major primal cuts, and chemical composition of muscle tissue) in broilers reared under intensive and semi-intensive systems.

\section{Materials and Methods}

This experiment involved a total of 400 day-old Hybro broilers. Previous studies (Bogosavljević-Bošković et al., 2006b, 2011) have revealed that this line of broilers can be successfully reared under free-range i.e. semi-intensive conditions; hence the authors deemed it justified to use this line in the present experiment as well.

Over an initial period of four weeks, the test broilers were reared indoor on deep litter floor. Then, on day 28 of age, the broilers were assigned to two groups: Group 1, including broilers reared indoor, and Group 2, comprising broilers that were provided a grass range of $1 \mathrm{~m}^{2} /$ bird. Length of the fattening period was 56 days. Broiler nutrition involved the use of complete compound feeds, including broiler starter diet (BS, manufacturer: Veterinary Institute Zemun, Republic of Serbia) until day 28 , and broiler finisher diet (BF, the same manufacturer) until day 42. From day 42 until the end of the fattening period, the broilers were fed a diet containing a mixture of ground maize, barley, mineral and vitamin supplements $(70 \%)$ and a complete compound feed (30\%). Feed provision was on an ad libitum basis.

Upon fattening, 15 male and 15 female broilers were randomly selected from each experimental group and slaughtered to examine major meat quality traits. Immediately prior to slaughter, the broilers were weighed. Upon slaughter, dressed carcasses were subjected to measurements. Thereafter, dressed cold carcasses were dissected into primal cuts (breast, drumstick, thigh, wing, pelvis and 
back) following the method prescribed by the Regulation on Poultry Meat Quality (Official Gazette of the SFRY Nos. 1/81 and 51/88). Primal cuts were weighed to determine the dressing percentage of the test broilers. The data obtained were used to calculate the percentage of individual meat classes. Then, major primal cuts, including breasts, thighs and drumsticks, were dissected into muscle tissues to evaluate their respective percentage. Muscle tissue was weighed and sampled for chemical analysis. The samples were stored at $-21{ }^{\circ} \mathrm{C}$ until analysis performed within one month from the sampling date.

The data obtained in this study were subjected to conventional methods of variation statistics. The significance of differences was tested by the following mathematical model of analysis of variance:

$\mathrm{Yijk}=\mu+(\mathrm{RS})_{\mathrm{i}}+(\mathrm{S})_{\mathrm{j}}+(\mathrm{RSS})_{\mathrm{ij}}+\mathrm{e}_{\mathrm{ijk}}$

The outlined model matched the 2 × 2 factorial design ( 2 rearing systems $\mathrm{RS}$, and 2 sexes $-\mathrm{S}$ ).

The test parameters underwent analysis of variance (ANOVA) using Microsoft STATISTICA Ver. 5.0., Stat Soft Inc. (2005).

All significant differences determined by analysis of variance and results of F-exp values were evaluated using LSD-test.

\section{Results and Discussion}

The percent yields of individual meat classes in dressed broiler carcasses are outlined in Table 1.

Table 1. Dressing percentage and proportion of individual meat classes (\%)

\begin{tabular}{|c|c|c|c|c|c|c|}
\hline \multirow{2}{*}{ Rearing system (RS) (1) } & \multirow{2}{*}{\multicolumn{2}{|c|}{$\operatorname{Sex}(2)$}} & \multirow{3}{*}{$\begin{array}{c}\begin{array}{c}\text { Dressing } \\
\text { percentage }\end{array} \\
65.44\end{array}$} & \multicolumn{3}{|c|}{ Meat classes } \\
\hline & & & & \multirow{2}{*}{$\begin{array}{c}\mathrm{I} \\
59.70\end{array}$} & \multirow{2}{*}{$\begin{array}{c}\text { II } \\
13.04\end{array}$} & \multirow{2}{*}{$\begin{array}{c}\text { III } \\
26.58\end{array}$} \\
\hline \multirow{4}{*}{ Intensive } & \multirow{2}{*}{ male } & $\bar{x}$ & & & & \\
\hline & & $\mathrm{Cv}$ & 1.90 & 2.94 & 6.84 & 6.94 \\
\hline & \multirow{2}{*}{ female } & $\bar{x}$ & 65.61 & 59.76 & 12.60 & 27.17 \\
\hline & & $\mathrm{Cv}$ & 2.04 & 3.52 & 5.12 & 7.54 \\
\hline \multirow{4}{*}{ Semi-intensive } & \multirow{2}{*}{ male } & $\bar{x}$ & 64.93 & 60.57 & 12.75 & 26.01 \\
\hline & & $\mathrm{Cv}$ & 1.72 & 2.76 & 5.47 & 6.25 \\
\hline & \multirow{2}{*}{ female } & $\bar{x}$ & 65.33 & 59.96 & 12.40 & 27.01 \\
\hline & & $\mathrm{Cv}$ & 1.37 & 3.88 & 6.10 & 8.77 \\
\hline \multirow{3}{*}{\multicolumn{2}{|c|}{$\mathrm{F}_{\exp }$}} & $\mathrm{F}_{1}$ & & $1.093^{\mathrm{ns}}$ & $1.599^{\mathrm{ns}}$ & $0.514^{\mathrm{ns}}$ \\
\hline & & $\mathrm{F}_{2}$ & & $0.266^{\mathrm{ns}}$ & $4.159^{*}$ & $2.315^{\mathrm{ns}}$ \\
\hline & & $\mathrm{F}_{12}$ & & $0.427^{\mathrm{ns}}$ & $0.044^{\mathrm{ns}}$ & $0.157^{\mathrm{ns}}$ \\
\hline
\end{tabular}

$\overline{\bar{x}}$ - Average, $\mathrm{Cv}$-Index of variation, ${ }^{\mathrm{ns}}-\mathrm{P}>0.05 ;{ }^{*}-0.01 \leq \mathrm{P} \leq 0.05 ;{ }^{* *}-\mathrm{P}<0.01$ 
Table 1 shows that the highest percentage of class 1 meat was obtained in male broilers reared under semi-intensive conditions $(60.57 \%)$ and the lowest in males from intensive rearing $(59.70 \%)$. Smaller differences were observed between female broilers from the two experimental groups. The differences exhibited in terms of the percentage of class 1 meat were found to be significant $(\mathrm{P}>0.05)$. The range of values for class 2 meat of $12.40 \%$ (female broilers, semi-intensive system) to $13.04 \%$ (male broilers, intensive system) and class 3 meat of $26.01 \%$ (males, semi-intensive rearing) to $27.01 \%$ (females, semi-intensive system) suggests small differences between the percentage of class 2 and class 3 meat. Moreover, the differences observed were not statistically significant $(\mathrm{P}>0.05)$.

The percent yield of muscle tissue in major primal cuts is an important meat quality parameter in broilers. Table 2 presents the results on the percent yield of muscle tissue in breast, thighs and drumsticks (classified as class 1 meat in the Regulation on Meat Quality - Rašeta and Dakić, 1984).

Table 2. Percent yield of muscle tissue (\%)

\begin{tabular}{|c|c|c|c|c|c|}
\hline \multirow{2}{*}{ Rearing system (RS) (1) } & \multirow{2}{*}{\multicolumn{2}{|c|}{$\operatorname{Sex}(2)$}} & \multicolumn{3}{|c|}{ Muscle tissue } \\
\hline & & & Breasts & Drumsticks & Thighs \\
\hline \multirow{4}{*}{ Intensive } & \multirow{2}{*}{ male } & $\bar{x}$ & 65.78 & 59.11 & 69.28 \\
\hline & & $\mathrm{Cv}$ & 2.30 & 4.23 & 3.18 \\
\hline & \multirow{2}{*}{ female } & $\bar{x}$ & 67.49 & 59.26 & 69.34 \\
\hline & & $\mathrm{Cv}$ & 3.09 & 0.86 & 3.17 \\
\hline \multirow{4}{*}{ Semi-intensive } & \multirow{2}{*}{ male } & $\bar{x}$ & 68.28 & 57.24 & 72.36 \\
\hline & & $\mathrm{Cv}$ & 1.65 & 3.34 & 0.71 \\
\hline & \multirow{2}{*}{ female } & $\bar{x}$ & 69.85 & 58.25 & 72.66 \\
\hline & & $\mathrm{Cv}$ & 2.09 & 0.81 & 1.34 \\
\hline \multirow{3}{*}{$F_{\text {exp }}$} & & $\mathrm{F}_{1}$ & $7.902^{*}$ & $2.262^{\mathrm{ns}}$ & $13.344^{* *}$ \\
\hline & & $\mathrm{F}_{2}$ & $3.627^{\mathrm{ns}}$ & $0.344^{\mathrm{ns}}$ & $0.045^{\mathrm{ns}}$ \\
\hline & & $\mathrm{F}_{12}$ & $0.004^{\mathrm{ns}}$ & $0.199^{\mathrm{ns}}$ & $0.019^{\mathrm{ns}}$ \\
\hline
\end{tabular}

$\bar{x}$ - Average, $\mathrm{Cv}$-Index of variation, ${ }^{\mathrm{ns}}-\mathrm{P}>0.05 ;{ }^{*}-0.01 \leq \mathrm{P} \leq 0.05 ;{ }^{* *}-\mathrm{P}<0.01$

Table 2 shows that the percent yield of breast muscle tissue was higher in female broilers as compared to males, as well as in free-range broilers as compared to intensively reared broilers. However, Group 1 broilers had a higher percent yield of drumstick muscle tissue $(59.11 \%$ and $59.26 \%$ in males and females, respectively). Semi-intensive rearing resulted in the percent yield of $57.24 \%$ (males) and 58.25\% (females). The highest thigh content of muscle tissue $(72.66 \%)$ was produced in free-range semi-intensive female broilers and the lowest $(69.28 \%)$ in broilers reared under intensive system. 
Differences in the percent yield of breast muscle tissue and drumstick muscle tissue were found to be statistically significant $(\mathrm{P}<0.05)$ and very significant $(\mathrm{P}<0.01)$ in favour of semi-intensive broilers.

Regardless of a number of factors that hinder comparison with the literature data, the results of the present research are in agreement with those reported by Lewis et al. (1997), Ristić et al. (2003), Bogosavljević-Bošković et al. (2006).

The results on the protein and lipid contents in breast, drumstick and thigh muscles are presented in Table 3.

Table 3. Percentage of proteins and lipids in major primal carcass parts (\%)

\begin{tabular}{|c|c|c|c|c|c|c|c|c|}
\hline \multirow{2}{*}{$\begin{array}{l}\text { Rearing system } \\
\text { (RS) (1) }\end{array}$} & \multirow{2}{*}{\multicolumn{2}{|c|}{$\operatorname{Sex}(2)$}} & \multicolumn{2}{|c|}{ Breasts } & \multicolumn{2}{|c|}{ Drumsticks } & \multicolumn{2}{|c|}{ Thighs } \\
\hline & & & Proteins & Lipids & Proteins & Lipids & Proteins & Lipids \\
\hline \multirow{4}{*}{ Intensive } & \multirow{2}{*}{ male } & $\bar{x}$ & 23.48 & 2.10 & 21.88 & 4.46 & 19.96 & 7.92 \\
\hline & & $\mathrm{Cv}$ & 2.02 & 7.82 & 0.84 & 2.64 & 2.12 & 3.44 \\
\hline & \multirow{2}{*}{ female } & $\bar{x}$ & 23.16 & 2.34 & 19.96 & 6.04 & 18.88 & 9.20 \\
\hline & & $\mathrm{Cv}$ & 1.82 & 3.08 & 0.80 & 3.75 & 1.22 & 2.26 \\
\hline \multirow{4}{*}{ Semi-intensive } & \multirow{2}{*}{ male } & $\bar{x}$ & 23.82 & 1.92 & 22.12 & 3.66 & 19.98 & 7.06 \\
\hline & & $\mathrm{Cv}$ & 1.07 & 3.31 & 0.92 & 4.52 & 1.27 & 3.54 \\
\hline & \multirow{2}{*}{ female } & $\bar{x}$ & 23.48 & 2.16 & 21.72 & 3.48 & 19.02 & 7.84 \\
\hline & & $\mathrm{Cv}$ & 1.39 & 1.93 & 1.04 & 2.64 & 1.43 & 6.39 \\
\hline \multirow{3}{*}{$F_{\text {exp }}$} & \multicolumn{2}{|l|}{$\overline{\mathrm{F}_{1}}$} & $21.679^{* *}$ & $57.940^{* *}$ & $178.48^{* *}$ & $24.605^{* *}$ & $24.244^{* *}$ & $134.67^{* *}$ \\
\hline & \multirow{2}{*}{\multicolumn{2}{|c|}{$\mathrm{F}_{2}$}} & $0.507^{\mathrm{ns}}$ & $0.00^{\mathrm{ns}}$ & $3.482^{\mathrm{ns}}$ & $1.232^{\mathrm{ns}}$ & $0.023^{\mathrm{ns}}$ & $1.603^{\mathrm{ns}}$ \\
\hline & & & $0.010^{\mathrm{ns}}$ & $0.019^{\mathrm{ns}}$ & $0.007^{\mathrm{ns}}$ & $8.441^{* *}$ & $1.030^{\mathrm{ns}}$ & $1.113^{\mathrm{ns}}$ \\
\hline
\end{tabular}

$\bar{x}$ - Average, $\mathrm{Cv}$-Index of variation, ${ }^{\text {ns }}-\mathrm{P}>0.05 ;{ }^{*}-0.01 \leq \mathrm{P} \leq 0.05 ;{ }^{* *}-\mathrm{P}<0.01$

Table 3 shows that the protein content of breast muscles ranged from $23.16 \%$ (females, semi-intensive system) to $23.82 \%$ (males, semi-intensive system), and the lipid content from $1.92 \%$ (males, semi-intensive system) to $2.34 \%$ (females, intensive system). Both male and female broilers reared under semiintensive conditions had a somewhat higher protein content and a lower lipid content in breast muscles. The protein content of drumsticks was also higher, and the fat content was lower in free-range broilers than in intensively reared broilers.

Broiler thighs had a protein content of $19.98 \%$ (males, semi-intensive system) to $18.88 \%$ (males, intensive system), and a lipid content of $7.06 \%$ (males, semi-intensive fattening) to $9.20 \%$ (females, intensive fattening).

Overall, irrespective of relatively small differences, semi-intensive rearing involving access to free-range conditions resulted in a higher protein content and a lower lipid content in all major primal cuts of broiler carcass as compared to intensively reared broilers. 
The higher protein content of breast, drumsticks and thighs in broilers from semi-intensive system as compared to those reared under intensive conditions was confirmed by statistical analysis to show very significant differences $(\mathrm{P}<0.01)$.

The published data show substantial variation in the nutritional value of chicken meat. The present results on the protein and fat contents of white meat (breast muscle) and dark meat (leg muscle) complied with the findings obtained by Demby and Cunningham (1980). These authors reported the protein content of raw chicken meat of $17.0 \%$ to $23.3 \%$ (averaging $19.8 \%$ ) and the fat content of $1.0 \%$ to $17.45 \%$ (average $7.5 \%$ ). However, many variables, such as broiler hybrid or breed, age, sex, nutrition, rearing system, carcass dressing and type of meat, which can affect the nutritional value of meat can also induce small or large differences in the results obtained. High significant variability in terms of the fat content can also be due to the use of different sampling methods. Different authors have determined fat content either in muscle alone or in muscle-plus-skin, with subcutaneous fat being also included. Breast muscle-plus-skin was found by Holcman et al. (2003) to contain $20.4 \%$ protein and $7.0 \%$ fat on average. As for leg muscle-plus-skin, the average values as determined by the same authors were as follows: $16.8 \%$ protein and $13.1 \%$ fat.

Žlender et al. (1995) evaluated five different indoor-reared genotypes and reported the protein content of leg muscle and breast muscle-plus-skin to range from $15.8 \%$ to $17.9 \%$ and from $21.9 \%$ to $23.5 \%$, respectively. The fat content of thigh muscle ranged from $10.6 \%$ to $15.6 \%$ and that of breast muscle from $3.9 \%$ to $8.45 \%$.

Grashorn and Brose (1997) underlined that different production systems result in different meat quality. However, they reported higher differences only for extensive indoor broilers fattened according to the environmentally sound and controlled production standards, as opposed to label broilers (less intensive rearing conducted following the label concept) which produced meat quality similar to that obtained by broilers from conventional commercial production system. Muriel and Pascual (1995) found no significant differences in the protein content of muscles in indoor-reared male broilers slaughtered on day 85 of age and free range males slaughtered on day 81 . Indoor-reared broilers had a somewhat lower meat protein content as compared to free range broilers. Holcman et al. (2003) reported that the chemical composition of breast and leg muscle-plus-skin in broilers aged 56 days is not affected by fattening system employed in compliance with the regulations of the European Union on "extensive indoor" and "free range" production systems. Conversely, in his study on meat quality of five different broiler genotypes reared under ecological conditions, Ristić (2003) observed the effect of production system on the chemical composition of breast and drumstick meat. The results of our research (Bogosavljević-Bošković et al. 2004) also suggest the effect of rearing system and broiler sex on the protein and fat contents of breast and leg muscles. The above results can be attributed to the fact that extensive indoor rearing system and free range system involving access to natural environmental conditions (fresh air and sunlight) also resulted in differences in terms of the structural 
manifestations of tissues and organs, as well as in terms of the biochemical processes involved in the metabolism.

\title{
Conclusion
}

The results of the present study on the percentage of certain meat classes, percent yield of muscle tissue in breasts, thighs and drumsticks and their respective protein and fat contents suggest the following:

- No statistically significant differences in the percentage of class I, class II and class III meat were observed between rearing systems and broiler sex $(\mathrm{P}>0.05)$.

- Broilers reared under semi-intensive conditions had a higher percent yield of muscle tissue in breasts (statistically significant differences, $\mathrm{P}<0.05$ ), drumsticks (non-significant differences, $\mathrm{P}>0.05$ ) and thighs (statistically very significant differences, $\mathrm{P}<0.01$ ) as compared to broilers from intensive rearing.

- The protein content of breast, drumsticks and thighs was higher, and the lipid content was found to be lower in semi-intensively reared broilers as compared to intensively produced broilers, with the differences observed being statistically very significant $(\mathrm{P}<0.01)$.

Semi-intensive broiler rearing system was found to have an advantage over intensive rearing system in terms of both the percent yield of muscle tissue in breasts, drumsticks and thighs and the chemical composition of muscle tissue of class 1 meat.

\section{Acknowledgment}

This study is part of the BTR. 31033 project on Sustainable Conventional Production and Revitalized Traditional Production of Value-Added Poultry Meat and Eggs financially supported by the Ministry of Education and Science of the Republic of Serbia.

\section{Kompozicija trupova i hemijski sastav mesa tovnih pilića iz intenzivnog i poluintenzivnog načina gajenja}

\author{
S. Bogosavljević-Bošković, S. Mitrović, V. Dosković, S. Rakonjac, V. Kurćubić
}

\section{Rezime}

Sistemi gajenja živine već duži niz godina u mnogim zemljama sveta zaokupljaju pažnju i nauke i struke. Čine se brojni pokušaji da se u gajenju živine namenjene proizvodnji mesa i jaja inoviraju i ustanove nove tehnologije koje bi 
doprinele, pre svega, poboljšanju uslova gajenja, zaštiti životne okoline i koji bi osigurali bolji kvalitet živinskih proizvoda.

Polazeći od navedenog, cilj ovog rada bio je da se prikažu rezultati ispitivanja uticaja sistema gajenja na važnije osobine kvaliteta mesa (udeo osnovnih delova $u$ obrađenim trupovima, udeo tkiva $u$ važnijim osnovnim delovima i hemijski sastav mišićnog tkiva). Za istraživanje je poslužilo ukupno 400 pilića linijskog hibrida Hybro koji su gajeni na 2 različita načina (intenzivan i poluintenzivan). Po završetku tova i nakon klanja i primarne obrade trupova izvršena su neophodna merenja i uzeti su uzorci za analize hemijskog sastava mesa.

Rezultati ovog istraživanja pokazuju da su pilići odgajani na poluintenzivan način imali nešto veći udeo bataka i grudi, tj. mesa I kategorije, kao i veći udeo mišićnog tkiva u grudima i karabatacima. Osim navedenog, sadržaj proteina u mišićnom tkivu grudi, bataka i karabataka bio je veći kod pilića iz poluintenzivnog načina gajenja. S druge strane, sadržaj masti u navedenim osnovnim delovima bio je veći kod pilića iz intenzivnog načina gajenja.

U celini posmatrano, rezultati ovih istraživanja pokazali su da su pilići gajeni uz korišćenje ispusta tj. na poluintenzivan način u većini ispitivanih osobina postigli bolje rezultate u odnosu na piliće iz intenzivnog načina gajenja.

\section{References}

BOGOSAVLJEVIĆ-BOŠKOVIĆ S., PAVLOVSKI Z., PETROVIĆ M., RADOVIĆ V. (2004): Quantitative meat quality parameters of broilers from different rearing systems. Biotechnology in Animal Husbandry, 20, 3-4, 113-119.

BOGOSAVLJEVIC-BOSKOVIC S., KURCUBIC V., PETROVIC D.M., RADOVIC V. (2006a): The effect of sex and rearing system on carcass composition and cut yields of broiler chickens. Czech J. Anim. Sci., 51, 1, 31-38.

BOGOSAVLJEVIC-BOSKOVIC S., KURCUBIC V., PETROVIC M., DOSKOVIC V. (2006b): The effect of season and rearing system on meat quality traits. Czech J. Anim. Sci., 51, 8, 369-374.

BOGOSAVLJEVIC-BOSKOVIC S., PAVLOVSKI Z., PETROVIC D.M., DOSKOVIC V., RAKONJAC S. (2011): The effect of rearing system and length of fattening period on selected parameters of broiler meat quality. Archiv für Geflügelkunde, 75, 3 (in press).

DEMBY J.H., CUNNINGHAM F.E. (1980): Factors affecting composition of chicken meat-literature review. World Poultry Sci. J., 36, 25-37.

GRASHORN M.A., BROSE K. (1997): Quality assurance in label progras for chicken meat. Proceedings of XIII European Symposium on the Quality of Poultry Meat (619-624), Poznan, Poland, 21-26 September, 1997. 
HOLCMAN A., VADNJAL R., ŽLEDNER B., STIBILJ V. (2003): Chemical composition of chicken meat from free range and extensive indoor rearing. Arch. Geflügelkd., 67, 3, 120-124.

LEWIS P.D., PERRY C., FARMER L.J., PATTERSON R.L.S. (1997): Responses of two genotypes of chicken to the diets and stocking densities typical of UK and «Label Rouge» production systems:1. Performance, behaviour and carcass compsition. Meat Sci., 45, 501-216.

MURIEL A., PASCUAL M.R. (1995): Carcass and meat characteristics from free rangechickens. Proceedings of the XII European Symposium on the Quality of Poultry Meat, 219-222, Zaragoza, Spain, 25-29 September 1995.

RASETA J., DAKIĆ M. (1984): Higijena mesa (Higijena mesa živine i jaja). Veterinarski fakultet Beograd.

RISTIC M. (1999): Sensory and chemical criteria for broiler meat of different breeds from alternative levestock keeping. Proceedings of XIV European Symposium on the Quality of Poultry Meat, 291-294, Bologna, Italy, 19-23 September 1999.

RISTIC M. (2003): Fleischqualität von broiler aus der ökologischen produktion. Biotechnology in Animal Husbandry, 19, 5-6, 335-343.

RISTIĆ M. (2005): Influence of breed and weight class on the carcass value of broilers. In: XIIth European Symposium Quality of Poultry Meat, Doorwerth, The Netherlands: 23-26.

ŽLENDER B., HOLCMAN A., RAJAR A. (1995): The effect of provenance of chickens on dressing percentage and meat composition. Research Reports Biotechnical Faculty University of Ljubljana, Agricultural Issue (Zootechnica), Supplement 22, $3^{\text {rd }}$ International Symposium Animal Science Days. Perspectives in the production of various kinds of meat, 233-239, Bled, Slovenia, 26-29 September 1995. 